\title{
EFFECT OF BIODEGRADABLE PACKAGING ON THE SHELF-LIFE OF PASTEURISED WHOLE EGG MASS
}

\author{
Vjaceslavs Kočetkovs ${ }^{\#}$ and Sandra Muižniece-Brasava \\ Faculty of Food Technology, Latvia University of Life Sciences and Technologies, 22 Rīgas Str., Jelgava, LV-3004, LATVIA \\ \# Corresponding author, info@kocetkovs.com
}

Contributed by Sandra Muižniece-Brasava

\begin{abstract}
The aim of this study was to determine the effect of two types of packaging on the change in quality indicators of pasteurised liquid egg mass. Traditionally, the shelf-life of pasteurised liquid egg mass is up to 28 days. The increase in shelf-life would increase the exportation options of this product. The liquid egg mass was pasteurised on the equipment Ovobel AR56SH; the pasteurisation process continued for 60 minutes, reaching a maximum temperature from $65^{\circ} \mathrm{C}$ to 68 ${ }^{\circ} \mathrm{C}$ (hold time: 360 seconds). This paper focuses on two main packaging materials: high-density polyethylene (HDPE) and Tetra Rex® Bio-based. Forty-two samples of each packaging material were used to study the contents. Changes in the quality of samples during storage were estimated by measuring the total bacterial count (CFU/g) from 200 at the start of shelf-life up to $30 \times 10^{5}$ units (LVS ISO 4833-1:2014). Data in the test was explored with Anova: Single Factor statistical model and correlation method. Data that was obtained emphasises the importance of packaging type, which could provide stable quality of ready-to-use products for a duration of up to forty-five days.
\end{abstract}

Keywords: bio-based packaging, plastic packaging, liquid whole eggs mass.

\section{INTRODUCTION}

Shelled eggs are a perishable product and are consumed in large quantities in plastic packaging or moulded fibre egg packaging. According to EU regulation No. 589/2008, the shelf-life of an egg allowing the product to be used in ambient temperature is at least 28 days (Commission Regulation(EC) No.: 589/2008). Eggs are the staple food in the human diet and are consumed globally. They represent complete food required for well-being and are recognised by consumers as versatile with a balance of essential nutrients. However, eggs are perishable and susceptible to contamination with certain microorganisms (Abdulhakim et al., 2019). In the event of a decrease in the sales of shelled eggs, farmers need to process a fresh egg for other sales this product is whole egg liquid mass. Currently, this product can be implemented with an expiration date up 28 days. The shelf life of this product strongly depends on the selection of proper packaging (Commission Regulation (EC) No. 589/2008).

Packaging sets apart the products from the external environment and in general has four essential functions: protection, communication, convenience, and containment (Yam et al., 2005; Kocetkovs et al., 2019). Packaging is a protective shell that protects the product from shock, dirt, heat, light, bacteria, and other external factors. It has many functions, for example, protection of unprocessed or processed foods against contamination and other risks posed by the external environment (Omanovic-Mikličanin, 2017). Packaging is a crucial part of any advanced integrated product supply system. The main advantage is not just to preserve the product's integrity and features, starting with the production line and ending with the consumer impact on health and safety, but also to accelerate the production and distribution and improve storage options (Kruma et al., 2018). The material of the package can modify the product by physical and chemical alterations because of particle migration into the nourishment. Packaging contributes significantly to safe delivery and preservation of packaged food (Dobrucka and Cierpiszewski, 2014).

Permanent monitoring of packaging not only minimises surplus food waste, but also protects final consumers against potential food intoxication, maximises the efficiency of the 
food industries, and improves traceability (Kuswandi et al., 2011).

Preserving food quality is also an essential area of research, as it is directly associated with the global aim of improving the quality of our lives. Additionally, there is a growing demand by consumers concerning quality and safety properties. Food quality issues are highly dependent on the applied packaging materials (Sohail et al., 2018).

Despite the fact that smart and biodegradable materials are becoming increasingly important in the market, survey results in Latvia showed that respondents have insufficient knowledge of intelligent packaging (Kocetkovs et al., 2019).

In this industry, manufacturers are currently using other types of packaging, like HDPE, Tetra Brik® or Tetra Brik® Aseptic. Tetra Rex® Bio-based package will be used in the egg industry for the first time. Interest in well-being and healthy consumption habits is more significant than ever before. Packaging is a crucial factor in addressing all these aspects.

The results of the test with vegetables and fruit demonstrated that biodegradable packaging materials could be used as a successful alternative to conventional polymers for packaging of fresh-cut produce, and they can offer an essential contribution to the reduction of environmental pollution. Biodegradable packaging with high barrier protections can be widely applied for food packaging, providing an individual approach for each specific instance (Dukalska, 2013). This study aimed to analyse the differences in the effect on pasteurised liquid egg mass shelf-life between two types of packaging.

\section{MATERIALS AND METHODS}

Materials. Liquid egg mass from company Balticovo JSC was used in the study. Liquid egg mass was pasteurised using a plate pasteuriser Ovobel AR56SH. The pasteurisation process lasted from $65{ }^{\circ} \mathrm{C}$ to $68{ }^{\circ} \mathrm{C}$ for 60 minutes. After pasteurisation, the liquid product was packed in two kinds of packaging: the first samples were packed in $11 \mathrm{HDPE}$ bottles, 42 units of samples with code PEM-19H. The second samples were packed in Tetra Rex ${ }^{\circledR}$ Bio-based package 1 1, 42 units of samples with code PEM-19T. The first samples of PEM-19H were packed using a Gercini, and the second samples PEM-19T were packed using a Galdi RG50UCS. Pasteurised egg mass was stored at temperature $0{ }^{\circ} \mathrm{C}+4{ }^{\circ} \mathrm{C}$ for forty-five days with two types of packaging.

Methods. Total bacterial count (colony-forming units, CFU/g) was estimated according to standard LVS ISO 4833-1:2014 (Latvian National Accreditation Bureau, 2020). The criteria $\mathrm{pH}$ value determined according to standard GOST 31469-2012,14 and ISO 1842:1991, using a Jenway 3510 Benchtop PH Meter. For the calculation of mean arithmetical values and standard deviations, Microsoft Excel v16 software was used. The effect of factors and their interaction, and their significance ( $p$-value) was determined using the ANOVA one-factor statistical model and correlation analysis. Differences were considered statistically significant when $p<0.1$.

\section{RESULTS}

HDPE often replaces heavier materials like glass or metal, in part because our society and many companies are pursuing sustainability goals, such as reducing the amount of material used in packaging and products. "Lightweight and strong" can be perceived similarly as leaving less impact on the environment. Undoubtedly, packaging protects from three significant classes of external influences: chemical, biological, and physical (Kirse et al., 2017). HDPE packaging is neither processable, renewable, nor biodegradable and is difficult to recycle into useful barrier materials. BIObased packaging is renewable, recyclable, and biodegradable. However, it is an imperfect barrier material both before and after recycling, especially against air and water vapour (Shanmugam et al., 2018). HDPE packaging meets the requirements: Regulation (EC) No. 1935/2004 of the European Parliament and of the Council of 27 October 2004 on materials and articles intended to come into contact with food and repealing Directives 80/590/EEC and 89/109/EEC and Commission Regulation (EC) No. 2023/2006 of 22 December 2006 on good manufacturing practice for materials and articles intended to come into contact with food.

Bio-based food packaging materials and Biodegradable packaging is a new direction in the food industry (Robertson, 2008). Tetra Pack is a package whose materials, components and a grammage of layers are continuously being developed for optimal performance at minimum resource utilisation and materials. Such materials have been defined as "materials derived from renewable sources" (Van Tuil, 2000). Green polyethylene, known as Green Plastic, is made from sugarcane ethanol and a $100 \%$ renewable material. It has the same performance, properties, and versatility of applications as polyethylene produced from fossil fuels, which facilitates its use in plastics production and the traditional polyethylene recycling chain (Rui, 2020). Combined with different paper components, the biopolymer increases to $82 \%$ the percentage of renewable materials in the packaging. Storage and selected packaging influences the stability of nutrients, quality, and microbiological quality (Kruma et al., 2018) (Fig. 1).

The first criteria that describes product quality on the first day after production is total bacterial count $(\mathrm{CFU} / \mathrm{g})$. This criteria allows a maximum of $\leq 1 \times 10^{5}(\mathrm{CFU} / \mathrm{g})$ by method LVS ISO 4833-1:2014.

Pasteurised egg mass produced in the practical laboratories showed differences in value of the criteria - total bacterial count. Test results were transformed by applying the natural logarithm according to the standards for total bacteria count for both samples of packaging. Criteria $\ln 12$ was satisfied with total bacteria count max. $\leq 1 \times 10^{5}$ (CFU/g) (Fig. 2). 


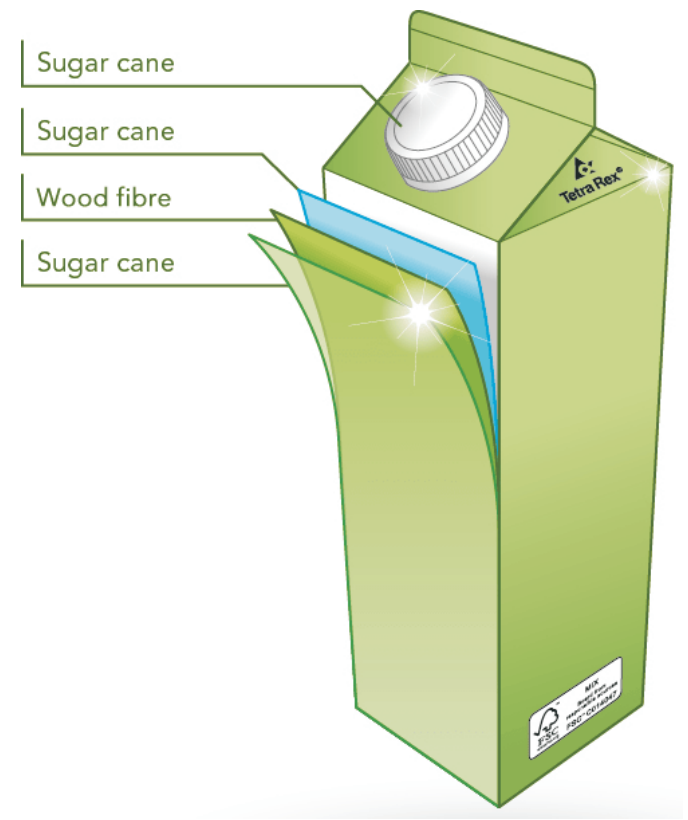

Fig. 1. Tetra Rex® Bio-based packaging by layers.

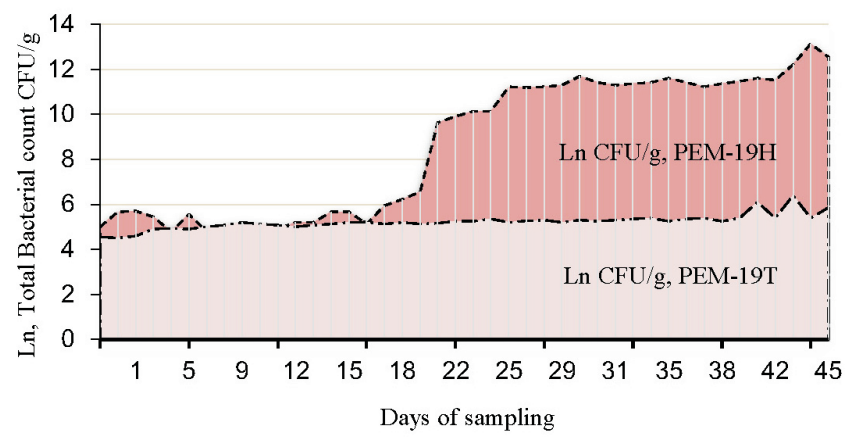

Fig. 2. The total bacteria count during the period of the 45 days shelf life: (ln CFU/g, PEM-19H) HDPE plastic packaging, (ln CFU/g PEM-19T) Tetra Pak Tetra Rex® Bio-based.

Only samples of the product PEM-19T passed the criteria for approved use. Pasteurised egg mass packaged in HDPE containers samples PEM-19H showed growth in the total bacterial count, and the bacterial count mostly began to increase on the twenty-second day of storage. Total bacterial count changes also occurred in Tetra Pack packaging, yet these changes were more subtle and did not affect the expiration date of the pasteurised egg mass. One of the essential applications of HDPE is in food packaging with the form of films. However, the migration of nanomaterials from packaging into food is a matter of concern because of the potential risk for exposed consumers (Grigoriadou et al., 2018).

Analysis of the total bacterial count over time showed significant differences between samples in the period of fortyfive days. Pasteurised eggs mass packed in Tetra Pak showed a stable indicator of the analysed criterion 197 $\mathrm{CFU} / \mathrm{g}$ units during the whole process of storing of the test materials. However, the HDPE packaging after 21 days of storage showed significant changes from 700 units to $2 * 10^{4}$ $\mathrm{CFU} / \mathrm{g}$. Such drastic changes indicate unstable microbiological quality in the packages (Table 1).
Table 1. Results of one-factor ANOVA. Values of criteria: Total bacterial count $(p<0.1)$ essential difference between the two kinds of packages with a probability of $99 \%$

\begin{tabular}{|c|c|c|c|c|c|c|}
\hline \multicolumn{2}{|l|}{ Groups } & Count & Sum & \multicolumn{2}{|c|}{ Average } & Variance \\
\hline \multicolumn{2}{|c|}{ Ln CFU/g, PEM-19H } & 42 & 361.99 & \multicolumn{2}{|c|}{8.62} & 9.37 \\
\hline \multicolumn{2}{|c|}{ Ln CFU/g, PEM-19T } & 42 & 219.32 & \multicolumn{2}{|c|}{5.22} & 0.11 \\
\hline $\begin{array}{c}\text { Source } \\
\text { of variation }\end{array}$ & SS & df & MS & $\mathrm{F}$ & $p$-value & F crit \\
\hline Between groups & 242.32 & 1 & 242.32 & 51.13 & $3.28 \mathrm{E}-10$ & 3.96 \\
\hline Within groups & 388.65 & 82 & 4.74 & & & \\
\hline Total & 630.97 & 83 & & & & \\
\hline
\end{tabular}

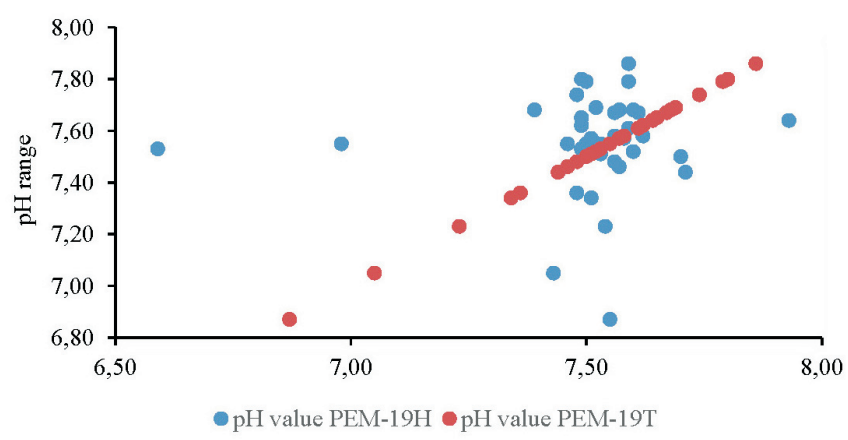

Fig. 3. 45 days shelf life: blue colours $\mathrm{pH}$ criteria (pH value PEM-19H) HDPE plastic packaging and red colours is the $\mathrm{pH}$ criteria $(\mathrm{pH}$ value PEM-19T) Tetra Pak Tetra Rex® Bio-based.

Chemical protection detects compositional changes triggered by environmental influences such as light (visible, infrared, or ultraviolet), moisture (gain or loss), or exposure to gases (typically oxygen). Many different packaging materials can ensure a chemical barrier (Marsh and Bugusu, 2007).

Manufacturers are currently using other types of packaging rather than HDPE - Tetra Brik® or Tetra Brik $\AA^{\circledR}$ Aseptic. Tetra Rex ${ }^{\circledR}$ Bio-based package will be used in the egg industry for the first time. Interest in well-being and healthy consumption habits is more significant than ever before. The packaging is a crucial factor in achieving all these aspects.

The second criterion which described the changes in product quality was $\mathrm{pH}$ value. This criterion did not significantly differ between the two kinds of packages (Fig. 3).

\section{DISCUSSION}

Packed pasteurised egg mass in HDPE packaging showed an unstable level of $\mathrm{pH}$ value until the expiration date up to forty-five days. Changes began to appear on the thirty-first day of the test. Packed product in Tetra Pack packaging showed a stable level of $\mathrm{pH}$ value. Both packaging materials guaranteed good quality for pasteurised egg mass up to thirty days. The second step must be to verify the expiration day count for this product in the same packaging for up to sixty days. The result obtained will significantly increase 
Table 2. Results of one-factor ANOVA: Result indicated that deviations in values do not differ significantly in values $\mathrm{pH}(p>0.5)$

\begin{tabular}{l|c|c|c|c|c|c}
\hline \multicolumn{1}{c|}{ Groups } & Count & Sum & Average & Variance \\
\hline $\begin{array}{c}\text { pH value PEM-19H } \\
\text { pH value PEM-19T }\end{array}$ & 42 & 315.57 & 7.51 & 0.04 \\
\hline \multicolumn{1}{c}{42} & 314.21 & 7.48 & 0.32 \\
$\quad \begin{array}{c}\text { Source } \\
\text { of variation }\end{array}$ & SS & df & MS & F & P-value & F crit \\
\hline $\begin{array}{l}\text { Between groups } \\
\text { Within groups }\end{array}$ & 0.02 & 1 & 0.02 & 0.12 & 0.73 & 3.96 \\
Total & 14.68 & 82 & 0.18 & & & \\
& 14.70 & 83 & & & &
\end{tabular}

the shelf life; the increase will be fifteen days more than existing approved standards (Table 2).

There are myriads of raw materials that can be employed for packaging production. For liquid eggs mass, either a polymer HDPE or Tetra Rex® Bio-based packaging is preferred (Marsh and Bugusu, 2007).

HDPE is high-density high-pressure polyethylene (HDPE plastic). It is a very reliable plastic, which does not emanate almost any harmful substances. The hard type of plastic is most often used for storing liquid product like milk, food products, detergents and is utilised in the production of a certain kind of plastic bags. This is the kind of material from which the majority of sports and reusable tourist bottles are made (Poyatos-Racionero et al., 2018). HDPE is valuable for its numerous indoor and outdoor applications owing to its remarkable properties, such as high toughness and impact strength, low thermal conductivity, ability to withstand humidity, and resistance to abrasion and corrosion (Grigoriadou et al., 2018). High-pressure polyethylene is inert to most chemicals, and has reasonable pricing and low energy demands for processing (Abhilash et al., 2020).

Correlation analysis showed direct dependence of three criteria on the type of packaging. The criterion total bacteria count directly depended on the type of packaging used, constitutes an indicator 0.6550 to 1 . The second and third criteria are protein and dry matter which showed values equal 0.7109 and 0.5470 to 1 (Table 3).

Carton packaging Tetra Rex ${ }^{\circledR}$ Bio-based is a modern, complicated, yet effective method for storing various foods. The primary material in all Tetra Pak packages is paperboard, and manufacturers use just enough material to make the package stable, without adding unnecessary weight (Sunga et al., 2013). Additionally, paperboard is a renewable material made from wood. Cardboard is the base of materials in Tetra Pak cardboard boxes. It ensures the stability, strength, and smoothness of the print surface. Polyethylene protects against outside moisture and enables the paperboard to stick to aluminium foil. Finally, aluminium foil protects against oxygen and light to sustain the nutritional value and flavours of the product in ambient temperatures (Kuorwel et al., 2011).

\section{CONCLUSIONS}

In the present study, both packages maintain the total allowable bacterial count for twenty-eight-days. However, starting from the $28^{\text {th }}$ day and up until the end of the study at the $45^{\text {th }}$ day, significant differences in the criterion total bacterial count (CFU/g) were observed: HDPE maximum 12.54 units Ln (CFU/g) and Tetra Pak Tetra Rex ${ }^{\circledR}$ Bio-based maximum 5.86 units $\mathrm{Ln}(\mathrm{CFU} / \mathrm{g})$.

After the $40^{\text {th }}$ day, the packaged pasteurised liquid egg mass in the Tetra Pak Tetra Rex ${ }^{\circledR}$ Bio-based package showed insignificant deviations from the tests carried out in the first week after production. Nevertheless, for the product packed in HDPE package the bacterial count increased from 700 units to $2 * 10^{4} \mathrm{CFU} / \mathrm{g}$ and in the samples PEM-19H and PEM-19T this can be noticed when examining the number of microorganisms per gram.

Criterion $\mathrm{pH}$ did not significantly differ between HDPE package and Tetra Pak Tetra Rex® Bio-based package.

Both packaging materials are permissible for production as they protect the product from exposure to light, reduce the percentage of moisture during storage, and guarantee safety following acceptable quality requirements for the finished product. Still, only the sample PEM-19T in Tetra Pak Tetra Rex ${ }^{\circledR}$ Bio-based can provide an expiration date for pasteurised egg mass up to forty-five days.

Table 3. Correlation analyses among changes in criteria: total bacteria count, dry matter, $\mathrm{pH}$ value and protein value in comparison of two types of packaging, PEM-19H - HDPE plastic packaging and PEM-19T Tetra Pak Tetra Rex® Bio-based

\begin{tabular}{|c|c|c|c|c|c|c|c|c|}
\hline & $\begin{array}{l}\text { Ln CFU/g, } \\
\text { PEM-19H }\end{array}$ & $\begin{array}{l}\text { Ln CFU/g, } \\
\text { PEM-19T }\end{array}$ & $\begin{array}{c}\text { dry matter } \% \\
19 \mathrm{H}\end{array}$ & $\begin{array}{c}\text { dry matter } \% \\
19 \mathrm{~T}\end{array}$ & $\begin{array}{c}\mathrm{pH} \text { value PEM } \\
-19 \mathrm{H}\end{array}$ & $\begin{array}{c}\mathrm{pH} \text { value PEM } \\
-19 \mathrm{~T}\end{array}$ & protein $\mathrm{H} \%$ & protein $\mathrm{T} \%$ \\
\hline Ln CFU/g, PEM-19H & 1 & & & & & & & \\
\hline Ln CFU/g, PEM-19T & 0.6550 & 1 & & & & & & \\
\hline dry matter $\% 19 \mathrm{H}$ & -0.0983 & -0.1034 & 1 & & & & & \\
\hline dry matter $\% 19 \mathrm{~T}$ & 0.3278 & 0.5470 & -0.0104 & 1 & & & & \\
\hline $\mathrm{pH}$ value PEM-19H & 0.2285 & 0.0721 & -0.1051 & 0.0430 & 1 & & & \\
\hline $\mathrm{pH}$ value PEM-19T & -0.0779 & -0.0190 & 0.2501 & 0.0269 & 0.0779 & 1 & & \\
\hline protein $\mathrm{H} \%$ & -0.0073 & 0.0372 & 0.3203 & 0.3445 & -0.2894 & 0.2130 & 1 & \\
\hline protein $\mathrm{T} \%$ & 0.0461 & 0.2216 & 0.1501 & 0.7109 & 0.0745 & 0.0867 & 0.1241 & 1 \\
\hline
\end{tabular}




\section{ACKNOWLEDGEMENTS}

Publication and dissemination of the research results have been made due to the funding of the Rural Support Service of the Republic of Latvia project "Development of smart packaging for liquid egg products", project No. 19-00-A01620-000087.

\section{REFERENCES}

Abdulhakim, S. E., Salam, A. I., Tahergorabi, R. (2019). Egg quality and safety with an overview of edible coating application for egg preservation. J. Food Chem., 296, 29-39.

Abhilash, S. S., Luckose, R., Singaravelu, D. L. (2020). Processing and characterisation of HDPE and MDPE processed by rotational moulding. Mater. Today Proc., 27 (3), 2029-2032.

Commission Regulation (EC) No. 589/2008 of 23 June 2008 laying down detailed rules for implementing Council Regulation (EC) No. 1234/2007 as regards marketing standards for eggs. 2005. Offic. J. Eur. Union, L163, $6-23$.

Dobrucka, R., Cierpiszewski, R. (2014). Active and intelligent packaging food - research and development: A review. Polish J. Food Nutr. Sci., 64 (1), 7-15.

Dukalska, L., Ungure, E., Augspole, I., Muizniece-Brasava, S., Rakcejeva, T. (2013). Evaluation of the influence of various biodegradable packaging materials on the quality and shelf life of different food products. Proc. Latv. Univ. Agr., 30 (1), 20-34.

Grigoriadou, I, Pavlidou, E, Paraskevopoulos, K. M., Terzopoulou, Z., Bikiaris, D. N. (2018). Comparative study of the photochemical stability of HDPE/Ag composites. Polymer Degrad. Stabil., 153, 22-36.

Kirse, A., Galoburda, R., Muizniece-Brasava, S., Karklina, D., Skudra, L. (2017). Improvement of microbiological safety and shelf-life of pulse spreads through sous vide and high-pressure processing. Agron.Res., 15 (S2), 1304-1315

Kocetkovs, V., Muizniece-Brasava, S., (2019). Manufacturer and retailer, the introduction of smart packaging systems in the market of Latvia. In: $25^{\text {th }}$ Annual International Conference: Research for Rural Development 2019, 15-17 May 2019. Latvia University of Life Sciences and Technologies, pp. 222-226

http://www2.1lu.1v/research_conf/proceedings.htm (accessed 12.01.2022).
Kuorwel, K., Marlene, Cran, J., Sonneveld, K., Miltz, J., Bigger W. S. (2011). Antimicrobial activity of biodegradable polysaccharide and protein-based films containing active agents. J. Food Sci., 76 (3), 90-102.

Kuswandi, B., Wicaksono, Y., Jayus, Abdullah, A., Heng, L. Y., Ahmad, M. (2011). Smart packaging: Sensors for monitoring of food quality and safety. Sensing Instrum. Food Qual. Safety, 5, 137-146.

Kruma, Z., Galoburda, R., Tomsone, L., Gramatina, I., Senhofa, S., Straumite, E., Klava, D., Kince, T., Cinkmanis, I., Zagorska, J., Kunkulberga, D. (2018). Changes in the nutritional value of breakfast cereals containing germinated spring grain flakes during storage. Agron. Res., 16 (S2), 1405-1416.

Latvian National Accreditation Bureau (2020). Registration No LATAK-T-544-05-2015, Accreditation Standard: LVS EN ISO/IEC 17025:2017.

https://www.latak.gov.lv/index.php?option=com_institucijas\&view=pdf $\& \mathrm{id}=8933 \& \mathrm{apl}=34000 \&$ lang $=\mathrm{lv}$ (accessed 12.01.2022).

Marsh, K., Bugusu, B. (2007). Food packaging-roles, materials, and environmental issues. J. Food Sci., 72 (3), 39-55.

Omanovic-Mikličanin E. (2017). Smart food packaging. In: Conference paper: "Works of the Faculty of Agriculture University of Sarajevo", Sarajevo, Vol. 62, No. 67 (2), pp. 702-708.

Poyatos-Racionero, E., Ros-Lis, J.V., Vivancos, J.-L., Martines-Manez, R (2018). Recent advances on intelligent packaging as tools to reduce food waste. J. Cleaner Prod., 172, 3398-3409.

Rui, M. S. C. (Ed.) (2020). Food Packaging. Innovations and Shelf-Life. CRC Press Taylor \& Francis Group, Boca Raton. 288 pp. Chapter 2. Packaging Biodegradability.

Robertson, G. (Ed.) (2008). Biobased food packaging materials: New directions. In: Chielliny, E. (Ed.) Environmentally Compatible Food Packaging. Woodhead Publishing Ltd, Cambridge, pp. 1-24.

Sohail, M., Sun, D.-W., Zhu, Z. (2018). Recent developments in intelligent packaging for enhancing food quality and safety. Crit. Rev. Food Sci. Nutr., 58 (15), 2650-2662

Sunga, S. Y.,Tin Sina, L.,Tiam-Ting T. (2013). Antimicrobial agents for food packaging applications. Trends Food Sci. Technol., 33, 110-123.

Shanmugam, K., Doosthosseini, H., Varanasi, S., Garnier, G., Batchelor, W. (2018). Nanocellulose films as air and water vapour barriers: A recyclable and biodegradable alternative to polyolefin packaging. Sust. Mater. Technol., 22, 1-8.

Van Tuil, R., Fowler, P., Lawther, M., Weber, C. J. (2000). Properties of biobased, packaging materials. In: Weber, C. J. (Ed.). Biobased Packaging Materials for the Food Industry - Status and Perspectives. KVL, Frederiksberg, Denmark, pp. 13-44.

Yam, K. L., Takhistov, P. T., Miltz. J. (2004). Intelligent packaging: Concepts and applications. J. Food Sci., 70, R1-R10.

Received 22 March 2021

Accepted in the final form 2 November 2021

\section{BIODEGRADĒJAMA IEPAKOJUMA IETEKME UZ PASTERIZĒTU OLU MASAS DERĪGUMA TERMIN̦U}

Pētījuma mērḳis bija novērtēt divu veidu iepakojumus ar pasterizētu škidro olu masu un izvērtēt produktu kvalitātes kritērijus derīguma termina laikā. Pētījumā izvēlēti iepakojumi: HDPE (augsta blīvuma polietilēns) un Tetra Pak Tetra Rex® Bio-based un analizēti četri kritēriji: kopējais baktēriju skaits, $\mathrm{pH}$, sausa viela un proteīns. Škiidrā olu masa tika pasterizēta 60 minūšu laikā, ražošanas procesa temperatūras režīms no $65^{\circ} \mathrm{C}$ līdz $68{ }^{\circ} \mathrm{C}$, turēšanas laiks - 360 sekundes. Pasterizētā škidrā olu masa tika iepakota un tai tika noteikts derīguma termiňš līdz 45 dienām. Temperatūras režīms $0+4{ }^{\circ} \mathrm{C}$. Katru ceturto dienu tika veikti testi pēc četriem kritērijiem. Jutīgs kritērijs produkta kvalitātes izmaiņām ir kopējais baktēriju skaits, kas HDPE iepakojumā pēc 21 dienas no 700 vienībām pieauga līdz $2 * 10^{4}$ CFU/g. Savukārt kopējais baktēriju skaits Tetar Pak Tetra Rex® Bio-based iepakojumā atbilda 197 CFU/g vienībām. Pēc maksimālā kritērija $1 \times 10^{5}$ vienībām sausai vielai un $\mathrm{pH}$ kritērijiem starp abiem iepakojuma veidiem nebija izteiktas atškirības. 